https://doi.org/10.48009/2_iis_2009_349-354

\title{
A THEORETICAL FRAMEWORK FOR GOVERNMENT 2.0 IN DEVELOPING AND EMERGING ECONOMIES
}

\author{
Rhoda C. Joseph, Pennsylvania State University Harrisburg, ruj1@psu.edu
}

\begin{abstract}
This paper focuses on the global and country level implications of government 2.0 initiatives. Government 2.0 focuses on the interactive components of e-government. Government 2.0 interaction ranges from message board entries to more sophisticated options such as polls and electronic voting. The implications of the government 2.0 phenomenon can be far-reaching particularly for emerging and developing regions of the world. This paper presents a theoretical framework for a country level context of government 2.0 initiatives, with specific attention to emerging and developing economies. There are several factors that can drive the growth of an emerging government 2.0 platform. This paper specifically focuses on e-participation and mobile technology, which arguably are key issues separating government 1.0 from government 2.0. The paper further examines the specific challenges of implementing government 2.0 initiatives.
\end{abstract}

Keywords: e-government, government 2.0, eparticipation, mobile technology, developing economies

\section{INTRODUCTION}

The area of e-government has grown and developed globally over the last decade. Broadly defined, e-government refers to the use of information technology by government entities to deliver services and products to citizens, businesses, employees, other governments, special interest groups and any other constituents that interact with the government. The world-wide-web represents a primary tool facilitating the growth and development of e-government applications. The most recent e-government report by the United Nation (2008) found that 189 countries globally have developed an e-government website [1].

In general e-government can be classified into four main categories based on the entity that interacts with government. The four main categories are government-to-citizen (G2C); government-toemployee (G2E); government-to-business (G2B) and government-to-government (G2G). Early stages of e-government development have traditional began with static non interactive web-pages that push information to citizens. These initial undertakings usually progress over time to include features for other groups beyond citizens such as employees, businesses, and other governmental agencies that are interested in government services and products. Services tailored towards employees and other government agencies coincide with strategic improvements and business process re-engineering of internal functions. As a country's e-government platform matures, additional features beyond only static features are included to contain varying degrees of interactivity.

As nations forge ahead with aggressive e-government agendas, some will advance at a faster rate than others. Given global economic challenges, the pace of growth of e-government projects can be severely thwarted because of constraints on already limited resources. The boundaries placed on resources may result directly from government agencies rechanneling resources to other areas instead of information technology projects. It is thus critical to examine the potential future growth of e-government through an alternate set of lens such as moving to the government 2.0 frameworks. Through the use of innovative government 2.0 applications, e-government growth in many developing regions of the globe can still forge ahead by exploiting the existing infrastructure and honing in on specific user needs. This means that e-government development will not proceed in a traditional sequential evolutionary manner, but instead undulate and maneuver to overcome local, regional and global obstacles.

\section{GLOBAL IMPLICATIONS OF E- GOVERNMENT}

The e-government phenomenon has made an imprint on the global landscape. E-government has traversed the globe and made its way from developed countries to emerging, and developing economies. Individual nations have embraced the transformative powers of 
e-government initiatives, and value the benefits that can be derived from its successful implementation. At the global level, governments in most countries have at a minimum implemented a static web-page for users to peruse.

Initiatives throughout Europe, North America, Eastern Asia, and Australia highlight projects that are benchmarks and represent great success in the area of e-government. Table 1 identifies the top ten global e-government leaders as identified by the United Nations in 2008. Programs such as CompraNet and DeclaraNet in Mexico, along with Chile's AgendaDigital highlight additional innovative and successful e-government projects specifically in Latin America[2]. Developing nations of the world are also key innovators in the development, implementation and promotion of e-government projects.

Table 1: Top Ten Global E-government Leaders[1]

\begin{tabular}{|l|l|l|}
\hline Rank & Country & Region \\
\hline 1 & Sweden & 0.9157 \\
\hline 2 & Denmark & 0.9134 \\
\hline 3 & Norway & 0.8921 \\
\hline 4 & United States & 0.8644 \\
\hline 5 & Netherlands & 0.8631 \\
\hline 6 & Republic of Korea & 0.8317 \\
\hline 7 & Canada & 0.8172 \\
\hline 8 & Australia & 0.8108 \\
\hline 9 & France & 0.8038 \\
\hline 10 & United Kingdom & 0.7872 \\
\hline
\end{tabular}

\section{GOVERNMENT 2.0}

Government 2.0 transforms government services from rigid bureaucratic structures to more efficient and dynamic entities. Government 2.0 promotes the use of innovative technologies to improve the delivery and exchange of government information for areas such as education, taxation, regulation and compliance, with the goals of achieving greater transparency and productivity[3]. When compared to government 1.0, government 2.0 is as much an internal as it is an external transformation of the way that a government operates. Government 1.0 represents the traditional industrial age models that are static bureaucratic silos, that are ill equipped to response to the dynamic needs of the information age[3].

The term government 2.0 can be associated with the web 2.0 phenomenon. Web 2.0 refers to both products and services such as blogs, wikis, real simple syndication (RSS), search engines, and other interactive features that facilitate dynamic boundaries between developers and users. Web 2.0 harnesses the potential of open source applications and serves as a driver for innovative web applications [4]. As governments take more of their products and services online, there is a greater shift towards identifying the value of interactive user components. The web 2.0 platform serves as a key benchmark to launch interactive e-government services for user.

Many countries that are physically proximal to each other and share common visions and goals have established regional blocs. Examples of such regional blocs include European Union - Europe; Caricom Caribbean; Mercursor - South America; and the African Union - Africa. Government 2.0 applications are relevant to both the individual countries and the regional entities. In additional to individual challenges that each nation faces with implementing effective government 2.0 applications, there are also regional factors that must also be considered. Regional factors highlight the specific nuances associated with inter-country transactions. With such complex environments interoperability challenges can occur at both the data and semantic levels[5]. As nations and regions forge ahead with their government 2.0 agenda there will be focused attention of minimizing as well as resolving interoperability challenges.

\section{E-PARTICIPATION}

The United Nations e-government survey evaluated and measured e-participation along three different dimensions: 1. E-information: availability of government products and services through tools such as newsgroups, forums, blogs, chat and text messaging; 2. E-consultation: availability of interactive tools for citizens to provide direct feedback to elected officials and their representatives; and 3. E-decision-making: availability of outcomes and decisions made by government through the e-consultation process [1]. E-participation is characterized by interactivity and as a result, eparticipation is a core component of government 2.0 projects. The data collected for the U.N. e-government study was primarily based on the citizen perspective, also mentioned earlier as the G2C category. Certainly tourists, foreign nationals, expatriots and other "non-citizens" have cause to interact with government agencies. The term citizen is used loosely to cover all individuals that interact with the government via e-government tools. 
The nature of e-participation is such that it cannot be limited to only the citizen focus. Even though citizens represent the primary unit of contact with e-government other non-citizen entities must also be afforded consideration to interact in the e-government landscape. These additional entities include representatives from businesses, special interest groups, labor unions, other government agencies, and also employees. E-participation looks at how any interested entity can interact directly with the government via the e-government platform. E-participation is thus a cornerstone tenant in the government 2.0 environment.

Developmental models of e-government identify political participation, also referred to as e-democracy in some instances, as one of the more advanced stages in the evolution of e-government. This type of participation includes conducting polls about issues that are of concern to individuals and groups in the society. This type of highly interactive participation is also addressed by the U.N.'s 2008 e-consultation construct.

The issue of voting can be a highly charged process. This is particularly true where voters perceive that there is deception or lack of honesty and transparency in the voting process. The use of e-participation tools through an e-government website can either magnify or reduce the presence of improper behavior given the individuals involved. In regions or countries that score high on corruption indexes, the use of such e-participation tools may serve to further erode trust of government and agents of governments, in general.

E-participation is not a utopia for the transformation of e-government products and services from a static to a more interactive government 2.0 environment. The goals of e-participation must be carefully examined and strategically planned to account for overall perceptions and trust or distrust of government entities and agents. E-participation has the potential to radical transform governments from static bureaucratic islands to interactive modules of administration. In the midst of all this progress, however, the management of user perceptions is a critical factor affecting successful implementation of the technology.

\section{MOBILE APPLICATIONS AND GOVERNMENT 2.0}

For some emerging and developing countries, the key to advancing government 2.0 technologies may lie with mobile applications. Interestingly, many developing regions of the world that have lagged behind other countries with respect to the development of telephone lines and wired broadband infrastructure[6]. However, the diffusion and adoption of cellular phones is pervasive in many countries in the Caribbean, Latin America, and Africa, where copper telephone lines are limited. Affordability and accessibility of these products and services have led to a burgeoning of the cellular market in developing regions.

Cellular phones by definition represent interactive technology. Harnessing the potential of cellular technology can potentially bypass many of the existing limitations with the implementation of traditional web-based e-government development. Taking the government 2.0 applications directly to the masses via cellular technology will transform the evolutionary trajectory of e-government development, by bypassing fixed land line implementation and going directly to mobile applications. Today mobile applications are key drivers for the transformation of government[7]. There are a myriad of applications that can support government 2.0 development including cell phones, pagers, PDAs, global positioning systems, and specialized hand held devices.

For the most recent decade of collected data, diffusion of mobile technology has been most rapid in the developing world. Low income and lowermiddle income countries have seen the most significant increase in the use of mobile phones (Table 2). Mobile phones can serve as a primary tool in the delivery of government 2.0 services.

Table 2: Global Cellular Subscribers [6]

\begin{tabular}{|l|c|}
\hline World Income Group & $\begin{array}{c}\text { Percentage Change of Cellular } \\
\text { Subscribers / Per 100 people } \\
\text { (1995-2004) }\end{array}$ \\
\hline $\begin{array}{l}\text { High Income } \\
\text { Countries }\end{array}$ & 28 \\
\hline $\begin{array}{l}\text { Upper-Middle } \\
\text { Income Countries }\end{array}$ & 58 \\
\hline $\begin{array}{l}\text { Lower-Middle } \\
\text { Income Countries }\end{array}$ & 61 \\
\hline $\begin{array}{l}\text { Low Income } \\
\text { Countries }\end{array}$ & 92 \\
\hline World & 37 \\
\hline
\end{tabular}




\section{THEORETICAL FRAMEWORK}

Several different factors affect the level and quality of a country's commitment to and development of a government 2.0 agenda. Each country will face a unique set of goals, timelines and milestones with respect to its e-government platform. In some instances regional pressure and/or support can either hamper or facilitate the pace of growth.

Two factors that can have a direct effect on government 2.0 success are the level of user participation (e-participation) and the level of technical infrastructure to support the interactive applications. For many developing economies, the growth of wireless technology has outpaced the rate of development and adoption of wired networks. For the growth of government 2.0 projects, e-participation and wireless applications are two areas worthy of detailed examination. Additional factors such as cost, managerial support, employee and end-user training, usability, reliability, security and interoperability all affect the development of e-government projects.

Figure 1: Theoretical Framework

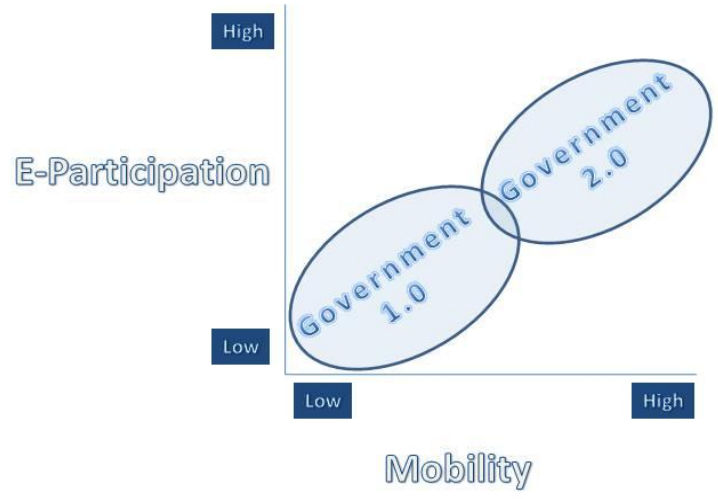

However, given the transformative and interactive characteristics of government 2.0 application, e-participation and mobile infrastructure are particularly relevant. As a result, even though there can be an infinite set of factors to consider, the theoretical model presented in this paper hones in on two core components: e-participation and mobility.
The boundary between government 1.0 and government 2.0 is not always clearly discernable but contrasts occur with the level of e-participation, and the utilization of mobile applications (figure 1). In many instances movement from government 1.0 to government 2.0 involves building on the 1.0 platform and incorporating interactive features that define government 2.0

\section{CHALLENGES TO GOVERNMENT 2.0 IN DEVELOPING REGIONS}

The implementation of e-government projects present opportunities for improved decision making and citizen participation, along with avenues for possible abuse[2]. More specifically, several challenges can occur with the implementation and global development of government 2.0 applications. Some specific challenges that can hinder the advance of government 2.0 particularly in emerging and developing economies include 1. global digital divide; 2. expectation-reality gap; 3. corruption; 4. limited information technology (IT) Infrastructure; and 5. resistance to change.

The global digital divide is a term that describes the differing levels of access to technology by people across the globe. The global digital divide is characterized by a myriad of social, economic and political factors. There is no single measure to assess the level of the divide but metrics such as a nation's teledensity, number of broad band users, per capita income, and literacy rates all seem to be related to the amount of and quality of access to technology of the citizenry[8]. For example in the Caribbean region, poorer nations had little to no delivery of government services to their citizens online, when compared to more affluent countries in the region[9].

The expectation-reality gap can affect both developers and users of e-government interactive systems. Developers can create intricate and complex models to address the needs of users. However, given budgetary restrictions and other unanticipated constraints projects may never come to fruition. The divide between the developers' vision and the actual finished project can be a challenge for the advancement of government 2.0 initiatives. Employees of government agencies can also become disenfranchised and frustrated if the government 2.0 initiative does not delivery all that it promised. To further exacerbate the situation, end-users such as citizens may also feel cheated if the e-government initiative does not function in the manner in which they expected it to. 
Increased government transparency can be a direct outcome of e-government project implementation. As governments move more services online it reduces the barriers that exist between themselves and other entities such as citizens and businesses. With the implementation of interactive government 2.0 features the magnitude of the increased transparency can be further amplified. For example, through e-consultation events, more users can be aware of the general sentiment about a particular issue that is being debated. At a country specific level, it has been theorized that in Japan, implementation of e-government applications can reduce high-level government corruption and improve the overall quality of governance[10]. Although Japan is a more economically developed country, there can also be critical lessons that are also applicable in developing countries.

However, along with increased transparency, there are also increased avenues for opportunists to game the system. Conniving individuals and groups can attempt to manipulate the content of e-consultation events and either directly or indirectly subvert the quality of individual participation that is expected. In spite of all the potential benefits, government 2.0 projects can present an easily accessible avenue for corrupt elements to sabotage and/or hijack the democratic process. Ultimately, various levels of corruption amongst government agencies and public administration officials can severely hamper the growth and value of government 2.0 initiatives. Interestingly, the biggest challenges associated with the implementation of seamless government 2.0 projects are not technical ones they are political[3].

The technical infrastructure of a country is critical to the success of e-government projects. Government 2.0 platforms need to support interoperability of a variety of hardware and software products and they also require more resources than static web-pages. Most government 2.0 services will require database servers that can support real-time queries and information updates from users. Effective telecommunications networks (both wired and wireless) will also be needed to increase the functionality and reliability of government 2.0 products. Consequently, under-developed or poorly implemented IT infrastructure in any country can thwart the pace of growth of government 2.0 products. The U.N.'s ten least e-government ready nations were all located on the African continent. This standing is directly correlated with limited development of underlying IT infrastructure. In 2008, the African continent had the smallest percentage of global penetration of internet users at $5.6 \%$ compared

Volume X, No. 2, 2009 to the leader North America at $73.1 \%[11]$. Yet, the African continent has shown the largest global growth with respect to the adoption of mobile technology. This provides a very strong case for circumventing wired telecommunications access to the internet. In such regions, wireless applications present a more direct route and effective route for the implementation of government 2.0 projects.

Lastly, the fifth factor that can retard a country's advance towards government 2.0 is individual and organizational resistance to change. As government agencies attempt to transform themselves and use more updated technology they can experience resistance from many areas including employees, managers, division leaders, businesses and various special interest groups that are invested in maintaining the existing status quo[3]. Government bureaucracies usually are entrenched in a particular culture and mode of operation and unwilling to transform when new ideas and methods are introduced. Eggers suggests that one effective method to bring about change in the government domain is to engage the interest and support of the political leadership[3] . Senior level well connected executives that are truly invested in the project can serve as strong advocates for the advancement of a country's government 2.0 agenda.

\section{CONCLUSION}

E-government is an interdisciplinary area that encompasses tenants from public administration, computer science, information systems and management. As a result of its multi-faceted nature there are many complex and challenging issues that face the growth of e-government. Given economic, social, and political uncertainty in many areas of the world today, the promises of e-government may behampered. However, many countries have continued to pursue various levels of e-government implementation. The transformative power of e-government has now shifted the conversation from static government 1.0 applications to interactive and dynamic government 2.0 applications.

As government 2.0 projects forge ahead there are two key areas that can provide the catalyst for development. Interactive applications can only operate effectively if there is a bimodal flow of data. Hence, in the theoretical model presented in this paper, the significance of e-participation is identified as a key driver for government 2.0 growth. Citizens and businesses must use the systems for them to be truly successful. Secondly, developing nations of the 
world are rapidly adopting mobile technology. Mobile technology can indeed be the catalyst used to ignite the growth of government 2.0 applications in developing regions.

In this paper government 2.0 is discussed at the country level of implementation. The implementation of government 2.0 application can present many benefits to governments that need to interact with the citizenry but are limited by such factors as limited telephone lines and the digital divide. This paper also highlights additional factors such as an expectationreality gap, corruption, and resistance to change that can hamper the growth of government 2.0 initiatives. In the future, detailed individual country level analysis in developing regions can be done to comprehensively examine both inhibitors and drivers of the government 2.0 phenomenon.

\section{REFERENCES}

1. UNPAN (2008) United Nations eGovernment Survey 2008: From $e$ Government to

Connected Governance. Department of Economic and Social Affairs

Division for Public Administration and Development Management Volume, 246

2. Padget, J., E-government and E-democracy. IEEE Intelligent Systems, 2005. 20(1): p. 94-96.

3. Eggers, W.D., Government 2.0. 2005, Oxford: Rowman \& Littlefield Publishers, INC.

4. Gupta, J., Open Source Economics Driving Web 2.0 Innovation. Read Write Web http://www.readwriteweb.com/archives/ope n_source_economics.php 2007.

5. Peristeras, V., et al., A conceptual analysis of semantic conflicts in pan-European egovernment services. Journal of Information Science, 2008. 34(6): p. 877-891.

6. World Bank, Global Economic Prospects. http://www-

wds.worldbank.org/external/default/WDSCo ntentServer/WDSP/IB/2008/02/15/0003106 07_20080215110511/Rendered/PDF/42097o ptmzd0REVISED0GEP020081PUBLIC1.pd f, 2008. Data Accessed June 15, 2009.

7. Amailef, K. and J. Lu, m-Government: $A$ Framework of Mobile-based Emergency Response Systems, in Proceedings of 3rd International Conference on Intelligent
Systems and Knowledge Engineering. 2008: Xiamen, China. p. 1398-1403.

8. Bagchi, K., Factors Contributing to Global Digital Divide: Some Empirical Results. Journal of Global Information Technology Management, 2005. 8(3): p. 47-65.

9. Joseph, R.C. and P.I. Jeffers, E-Government Maturity in the Caribbean Nations. Journal of Global Information Technology Management 2009. 12(1): p. 52-70.

10. Choi, J.-W., Governance Structure and Administrative Corruption in Japan: An Organizational Network Approach. Public Administration Review, 2007. 67(5): p. 930942.

11. http://www.internetworldstats.com, Internet Usage Statistics. Date Accessed: March 4th 2009. 